\title{
ナマズ卵レクチンのがん治療への応用を目指した基礎研究
}

\author{
菅原栄紀
}

\section{Application of Lectin from Catfish Eggs to Cancer Therapy: A Fundamental Study}

\author{
Shigeki Sugawara \\ Division of Cell Recognition Study, Institute of Molecular Biomembrane and Glycobiology, Tohoku Medical \\ and Pharmaceutical University; 4-4-1 Komatsushima, Aoba-ku, Sendai 981-8558, Japan.
}

(Received June 3, 2018)

\begin{abstract}
Silurus asotus egg lectin (SAL) is an $\alpha$-galactoside-binding protein, isolated from the egg of catfish. It belongs to the rhamnose-binding lectin family that binds to Gb3 glycan (Gal $\alpha 1-4 \mathrm{Gal} \beta 1-4 \mathrm{Glc}$ ). SAL has resulted in the induction of early apoptosis in the Raji cell line, which is a Burkitt's lymphoma cell line expressing Gb3. The apoptosis was characterized by i) increased externalization of phosphatidylserin via multidrug resistance 1 P-glycoprotein (MDR1 P-gp), and ii) reduced cell size through the activation of voltage-gated potassium channel Kv1.3. Although the incorporation of propidium iodide (PI) was observed, SAL did not cause apoptosis in Raji cells. This event may be due to an increased expression of membrane-anchored tumor necrosis factor $\alpha(\mathrm{TNF} \alpha)$ and TNF receptor 1 (TNFR1) after the binding of $\mathrm{SAL}$ to Gb3. Moreover, SAL arrested the cell cycle at the $\mathrm{G}_{0 / 1}$ phase, thus inhibiting cell proliferation. The suppression of cell proliferation by SAL was likely due to the enhanced expression of p21 caused by the phosphorylation of ERK $\mathrm{K}_{1 / 2}$ through the Ras-MEK-ERK $1 / 2$ pathway. Combination of SAL with anti-cancer drugs was also examined in this study. Interestingly, SAL increased the incorporation of doxorubicin (Dox) into Raji cells, consequently enhancing its cytotoxic effect. Similarly, the cytotoxic effects of vinblastine and irinotecan were also significantly increased in Raji cells treated with SAL. These studies demonstrate that SAL may be applied to cancer therapy.
\end{abstract}

Key words__ Silurus asotus egg lectin; globotriaosylceramide; cell cycle arrest; anti-cancer drug

\section{1.はじめに}

ヒトにおける糖鎖形成では，数種類の糖が単純に 連結した直鎖構造ではなく, 多種の結合様式により 枝分かれした構造を有することから，糖鎖は情報分 子として, 多様性という点で核酸やアミノ酸よりも 優れていることが示唆されてきた. 1) しかし，一方 でその多様性が, タンパク質などの機能解明と比較 して糖鎖の持つ情報機能の解析を困難にしている一 因になっている，糖鎖の機能を理解する試みに，動 物から植物まで生物界全体に普遍的に存在し, 特定 の糖に対して特異的に結合する性質を持つレクチン が利用されてきた。現在まで，受精，発生，免疫， ウイルス感染などのメカニズムの一部は，いずれも 糖鎖とそれを認識するタンパク質であるレクチンと

東北医科薬科大学分子生体膜研究所分子認識学部門 （９981-8558 仙台市青葉区小松島 4-4-1）

e-mail: ssuga@tohoku-mpu.ac.jp

本総説は, 平成 29 年度日本薬学会東北支部奨励賞の受

賞を記念して記述したものである.
の特異的な相互作用に起因することが明らかにされ ている. ${ }^{2,3)}$ 近年の生命科学の進歩において, レクチ ンは，生体における情報分子として位置づけられる 糖鎖の受け手として注目されている．細胞内で作ら れるタンパク質のおよそ半分が糖鎖修飾を受けてい るとされ, 糖タンパク質の機能解析を行うにあたつ ても, 糖鎖及び糖鎖を認識するレクチンの重要性が 再認識されている.

古くから動物レクチンの原材料として卵が重用さ れており，筆者の研究室ではウシガエル卵より単 離・精製したシアル酸結合性レクチン (cSBL) に, 正常中皮細胞に対しては効果を示さず，悪性中皮腫 細胞選択的に細胞死を誘導する効果があることを見 い出した. ${ }^{4-6)}$

一方，魚卵には動物レクチンの二大ファミリーで あるガレクチンやC-タイプレクチンとは異なるユ ニークな糖特異性を有するレクチンが多数見つかつ ている. ${ }^{7,8)}$ このレクチンの特徵は，L-ラムノースや $\alpha$-ガラクトシドに対して非常に高い親和性を示し, 
かつ後述する特徵的な糖認識配列を共有することで

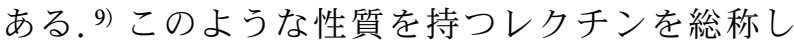
て，ラムノース結合性レクチン (rhamnose-binding lectin; RBL) という呼称が現在使用されている. ${ }^{9-14)}$ RBL の中には，がん細胞膜に発現しているスフィ ンゴ糖脂質の一種でセラミドに結合している三糖の 非還元末端にガラクトシル $\alpha$ 結合を持つグロボト リアオシルセラミド（Gb3）に結合することにより 細胞死を引き起こすものが報告されている. ${ }^{15-17)}$

本稿では，RBLの一種であるナマズ卵より得ら れたレクチン (Silurus asotus egg lectin; SAL) に着 目し, Gb3 を高発現しているバーキットリンパ腫 細胞株 Raji に対する作用を検討した結果を中心に 詳述するとともに，がん治療への応用の可能性を概 説する.

2. 魚卵由来ラムノース結合性レクチンについて サケ目，ナマズ目，キュウリウオ目，スズキ目及 びコイ目に属する多くの魚の未受精卵より RBL が 発見されている. 10-14,18-22) これらのタンパク質のア ミノ酸配列を比較すると類似した約 95 アミノ酸残 基よりなるドメインが 2 あるいは 3 つ並んだタンデ ムリピート構造を持つという特徵を持つことが明ら かとなっている。このドメインには，RBL モチー フと呼ばれている，よく保存された配列が存在し， $\mathrm{N}$-末端部に ANYGR 配列，C 末端部に DPC-KYL 配列がみられ，このドメインが RBL における糖結 合ドメイン (RBL-carbohydrate recognition domain; RBL-CRD）であると報告されている. ${ }^{11)}$ Nitta ら は，一次構造の類似性，ヒト赤血球凝集活性及びラ クトースによる阻害の有無から， RBL ファミリー を 5 つのタイプに分類し, ${ }^{23)}$ その後, Ogawa らによ り，タンパク質配列データベースを利用した包括的 な解析がなされ， RBL ファミリーが有する RBL$\mathrm{CRD}$ を進化的相同性の観点から 6 つに分類し (RBL-CRD1-6)，この RBL-CRD の組み合わせか ら 13 のサブタイプに分類された. ${ }^{24)}$ SAL は，RBLCRD が 3 つ並んだタイプ I a (CRD: 5-3-3) に分類 される。これまで，魚卵からは，1つの RBL-CRD よりなる RBL の報告はなされていないが，ウ二卵 からは，タンデムリピートではなく二量体としての RBL が見つかっている。 また，魚卵より単離・精 製されたという報告ではないが，2014 年に Thongdaらにより，RNA-sequencing（RNA-seq）デー夕
を利用し構築されたアメリカナマズ（Ictalurus punctatus) データベースから，このナマズには 6 つの異なる推定アミノ酸配列を有する RBL （IpRBL1a，1b，1c，3a，3b，5a）が存在することを示 し, このうち IpRBL5a は，1 つの RBL-CRD から なるものであることが報告された. ${ }^{25)}$

3. SAL によるホスファチジルセリン（phosphatidylserine; PS）の細胞膜外層側への移行及び細 胞縮小に関与する分子機構

細胞毒性を有するガラクトース結合性レクチンで ある ricin，abrin 及び misletoe（ヤドリギ）レクチ ンは, 細胞にPS の外層側への移行などアポトーシ ス様の変化をもたらし, 最終的に細胞死を引き起こ すことが知られている. ${ }^{26-28)}$ 一方， 2 量体化したガ レクチン-1 (dGal-1) は，PS の外層側への移行を 誘導するものの，アポトーシスを誘導しない. ${ }^{29)} こ$ れらのレクチンによる PS の細胞膜外層側への移動 に係わる分子機構はまだ明らかにされておらず，そ れぞれ異なる機構により引き起こされるものと考え られている。 また， RNA $N$-glycosidase 活性を持つ A サブユニット及びレクチンとして機能を有する B サブユニットから構成される AB-毒素の代表例で ある志賀毒素（Shiga toxin; Stx）は，細胞膜上に発 現している Gb3 に結合することにより，アポトー シスを誘導することが知られている. ${ }^{30)} \mathrm{SAL} も$ Gb3 に結合することから [Fig. 1(A)], Gb3 発現 細胞に対して細胞死を誘導できるのではないかと考 えたが，実験の結果，Raji 細胞において SAL 処理 による細胞死は認められなかった。しかし，一般的 にアポトーシス初期に起こることが知られている PS の細胞膜外層側への移行（アネキシン V の結合 で評価）及び細胞縮小が認められたため [Figs. 1 (B) and (C)]，これらの現象がごのような過程を経 て引き起こされるのか，またなぜ細胞死が誘導され ないのかという点について検討した.

PS の細胞膜外層側への移行に関与する分子を同

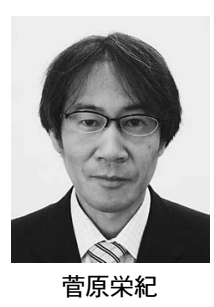

2000 年東北薬科大学薬学部卒業. 2002 年東北大学大学院薬学研究科修士課程 修了. 2005 年東北薬科大学大学院薬学 研究科博士課程修了. 同年同大学助手. 2007 年同助教. 2017 年東北医科薬科大 学薬学部講師, 現在に至る. 研究テー マと抱負：魚卵レクチンのがん治療へ の応用を目指した研究. 
A
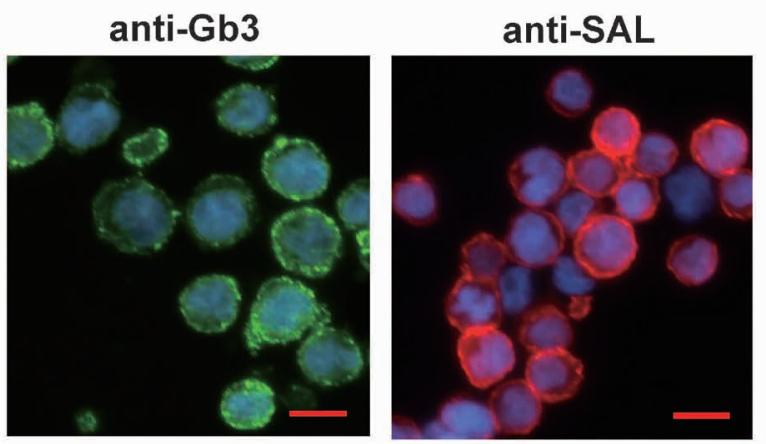

B
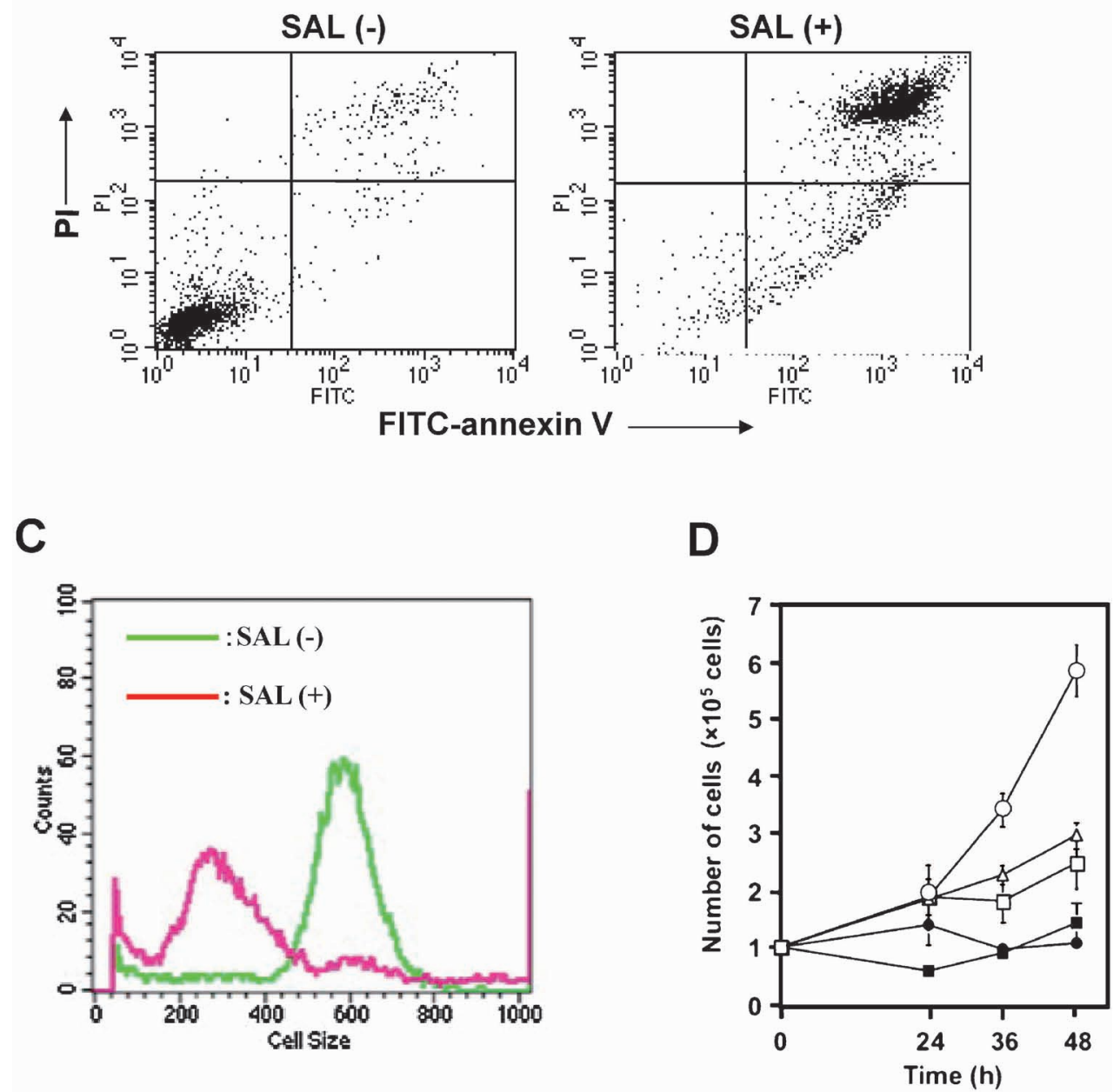

Fig. 1. Effect of SAL on Raji Cells

(A) Expression of Gb3 in Raji cells (green) and binding of SAL (red). (B) Externalization of phosphatidylserine (PS) and incorporation of propidium iodide (PI) in Raji cells. (C) Flow cytometry based data to shown shrinkage of Raji cells induced by SAL. (D) Reduction of proliferation of Raji cells by SAL as measured by trypan blue dye exclusion assay. Control $(\bigcirc) ; 1 \mu \mathrm{g} / \mathrm{mL}(\triangle) ; 5 \mu \mathrm{g} / \mathrm{mL}(\square) ; 50 \mu \mathrm{g} / \mathrm{mL}(\mathbf{\square}) ; 100 \mu \mathrm{g} / \mathrm{mL}(\mathbf{O})$.

定するため, 細胞膜脂質二重層を維持あるいは制御 する分子として知られている phospholipid scramblase (PLS), aminophospholipid translocase (APTL), ATP-binding cassette (ABC) transpoter に属する MDR1 P-gp 及び multidrug resistance protein（MRP）1に着目して検討を行った. ${ }^{31-34)}$ Raji
における PLS の発現レベルは非常に低く phospholipid 1-palmitoyl-1-[6-(7-nitro-2-1,3-benzoxadiazol4-yl) amino] dodecanoyl]-PC (NBD-PC) の取り込 みがほとんど認められなかったため, Rajiにおけ るPS の細胞膜外層側への移行に, PLS が関与して いる可能性は低いと考えた. ${ }^{35)}$ 一方, Raji 細胞では, 


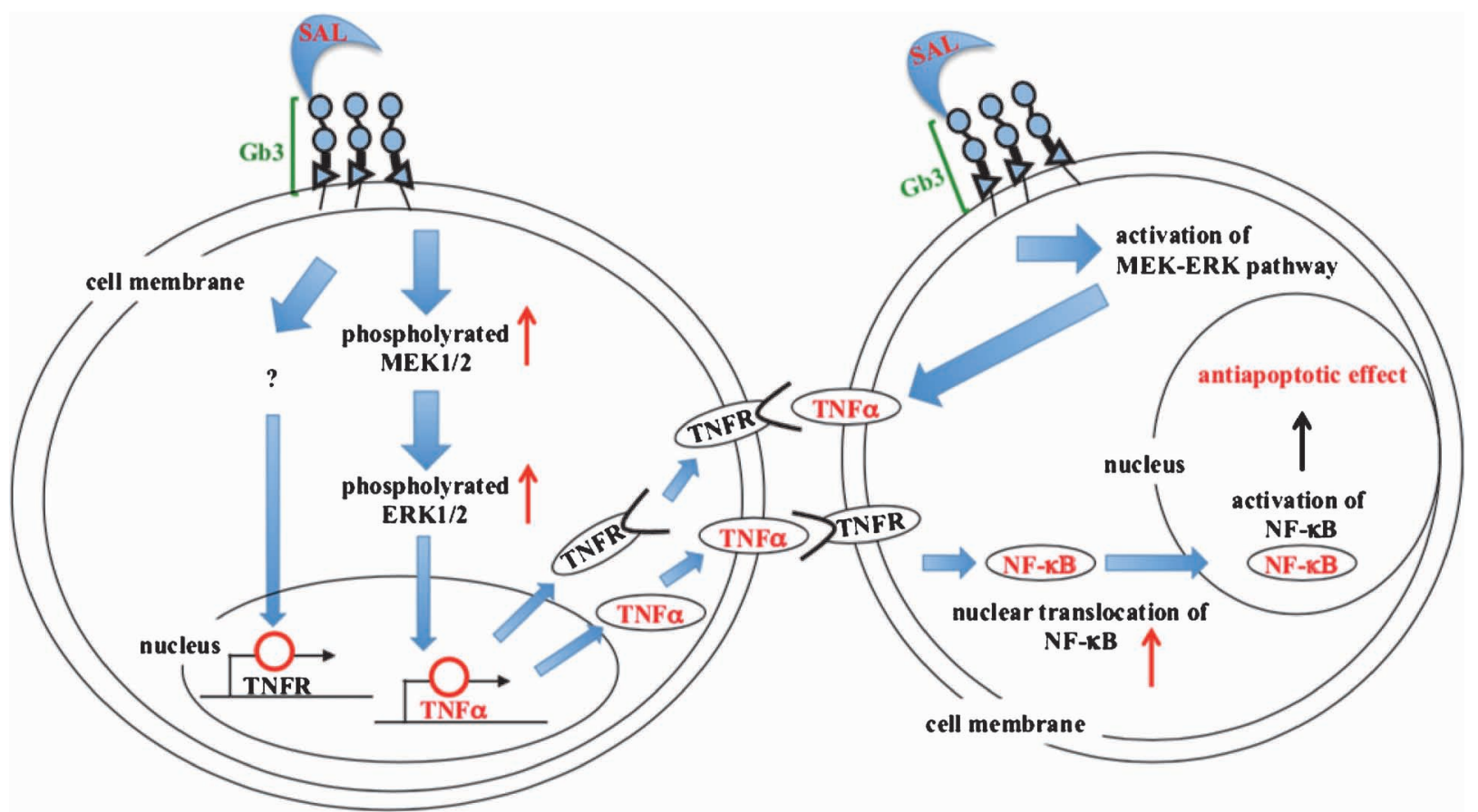

Fig. 2. An Insight into the Molecular Mechanism of Antiapoptotic Effect Caused by SAL

Treatment of Gb3 expressing Raji cells with SAL causes binding of TNF $\alpha$ to TNFR1, resulting in translocation of NF- $\kappa$ B, thus inducing an anti-apoptotic effect.

PS やホスファチジルエタノールアミン（PE）の細 胞膜外層から内層側への移行に関与している APTL の発現が非常に高いことが報告されていた が，こちらも SAL 処理 Raji 細胞における APTL 活性の減少は観察されなかった，以上のことから， PLS とAPTL はSAL が誘導するPS の移行には関 与していないと考えられた。次に，MRP1 及び MDR1 P-gp の関与について検討した．Raji 細胞に おいては, MRP1 の発現が高く, 反対に MDR1 P$\mathrm{gp}$ 発現は非常に低いものであった。次に，MDR1 $\mathrm{P}$-gp 阻害剤であるシクロスポリンA（cyclosporin A；CsA）及び MRP1 阻害剤である MRK16 を用い た実験を行った結果，SAL 処理によりPS の細胞膜 外層側への移行が CsA でのみ阻害された。これら の結果から，SAL は Raji 細胞膜上に発現している Gb3 に結合し，選択的に MDR1 P-gp を活性化して いることが示唆された. ${ }^{35)}$

細胞膜には, 膜内外の電位差の変化によって開閉 する電位依存型カリウムチャネル（voltage-gated potassium channel; Kv), カルシウムイオン又は他 のシグナル分子により開閉するカルシウム依存型カ リウムチャネル及び $\mathrm{G}$ タンパク質共役型の内向き 整流カリウムチャネルが発現している。このような
カリウムチャネルは，カリウムを選択的に細胞内に 流入あるいは排出することにより細胞の大きさを常 に一定に保つように㗢いている. ${ }^{36)}$ また，アポトー シスによる細胞縮小は，カリウムチャネルからのカ リウムイオンの流出によって起こることも知られて いる. ${ }^{37)} \mathrm{SAL}$ 処理した Raji 細胞でみられる細胞縮 小も同様な機構により起こるのかを検討した結果, SAL の処理時間及び濃度依存的に細胞内カリウム イオンの減少が認められた。一方，Gb3 を発現し ていないK562 細胞ではこのような現象はみられな いことから，これらの現象は SAL の Gb3への結合 が引き金となって引き起こされていることを示して いる，したがって，Gb3 に SAL が結合することに よりこのチャネルが活性化し, 細胞外へのカリウム イオンの放出と同時に水分子が流出するため, 腫瘍 細胞の縮小が引き起こされるというストーリーが推 測される. ${ }^{38)}$

4. SAL は tumor necrosis factor (TNF) $\alpha$ 及び TNF receptor（TNFR）の発現を増加させる

SAL は, Raji 細胞をアポトーシス初期状態に変 化させるが，結果的に細胞死を引き起こさない．な ぜ細胞死を誘導しないのか，その原因については不 明であった。 Watanabe らは魚由来の培養細胞であ 
る RTM5（繊維芽細胞）及び RTG-2（腹腔内マク ロファージ細胞）に対して CSL は, サイトカイン の一種である $\mathrm{TNF} \alpha$ と interleukin (IL) -8 の発現 を誘導することを報告し, ${ }^{39)}$ 筆者のデータからも $\mathrm{SAL}$ 処理 Raji 細胞において TNF $\alpha$ が上昇するとい う結果が得られている。TNF $\alpha$ には membrane form（膜結合型）と soluble form (可溶型) が存 在することが知られているが，SAL は膜結合型 $\mathrm{TNF} \alpha$ の発現を上昇させる効果を示す. 16) 後述にす るように，SAL は，ERK シグナル伝達機構を活性 化するため，膜結合型 $\mathrm{TNF} \alpha$ の発現上昇もこの機 構により引き起こされている可能性を考えている. また TNF $\alpha$ は, 細胞膜上に発現している TNFR に 結合することにより細胞内にシグナル伝えるが,

$\mathrm{SAL}$ は，TNF $\alpha$ の発現上昇だけではなく，その受 容体である TNFR1 及び TNFR2 の発現も上昇させ る. TNF $\alpha$ が TNFR に結合すると nuclear factorkappa B (NF- $\kappa \mathrm{B})$ が活性型に変化し，この NF- $\kappa \mathrm{B}$ が核内に移行することにより様々な遺伝子の発現が 誘導されることから，SAL 処理により活性型 NF$\kappa \mathrm{B}$ が核内に核移行することが明らかとなった. ${ }^{16)}$ Qin らにより，TNF $\alpha$ が TNFR1 に結合することに より抗アポトーシス作用を誘導することが報告され

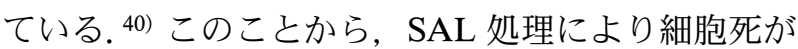
誘導されないのは，膜結合型 TNF $\alpha$ 及び TNFR1の 発現上昇によりこれらの分子を介して細胞同士が結 合することによる NF- $\kappa \mathrm{B}$ の抗アポトーシス効果が 原因ではないかと推察している（Fig. 2). 現在, $\mathrm{NF}-\kappa \mathrm{B}$ の核移行が抗アポトーシスに関与している のか否かを直接的に証明する実験に取り組んでいる.

5. SAL はバーキットリンパ腫細胞の増殖を抑 制する

上記のように，Raji 細胞を SAL 処理しても細胞 死は起きない. そこで, SAL の細胞増殖におよぼ す影響を検討したところ，100 $\mu \mathrm{g} / \mathrm{mL}$ の SAL 処理 で細胞増殖が止まることが分かつた [Fig. 1(D)]. さらに，この現象は，ハプテン糖により Gb3 に結 合した SAL を解離させると解除されることから, SAL の糖結合能が直接関与していると考えられ る. そこで，この細胞増殖抑制が細胞周期の停止に よるのか否かを検討したところ，SAL は細胞周期 を G1 期で停止させることにより細胞増殖を抑制し ている可能性が示された。細胞周期の G1 期から $\mathrm{S}$

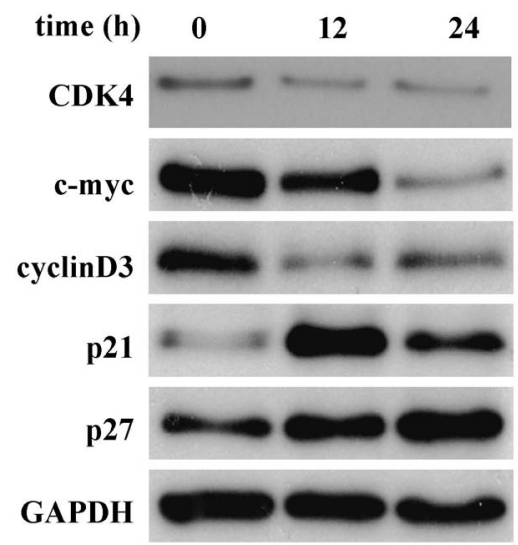

Fig. 3. SAL Alters the Expression of Proteins CDK4, cMYC, cyclin D3, p21, and p27

Cells $\left(1 \times 10^{6}\right)$ were treated with SAL $(100 \mu \mathrm{g} / \mathrm{mL})$ at $37^{\circ} \mathrm{C}$ for 0,12 , or $24 \mathrm{~h}$. Whole cell extract was subjected to western blotting using antibodies against CDK4, c-MYC, cyclin D3, p21, and p27.

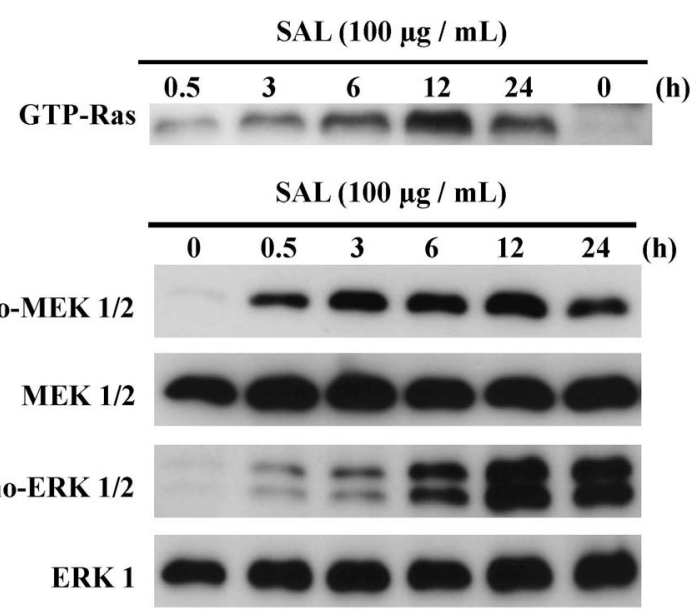

Fig. 4. SAL Causes Activation of Ras-MEK-ERK Pathway Cells $\left(1 \times 10^{6}\right)$ were treated with SAL $(100 \mu \mathrm{g} / \mathrm{mL})$ at $37^{\circ} \mathrm{C}$ for various durations from 0 to $24 \mathrm{~h}$. Whole cell extracts were subjected to western blotting using antibodies directed against $\mathrm{Ras}, \mathrm{pMEK}_{1 / 2}, \mathrm{MEK}_{1 / 2}, \mathrm{pERK}_{1 / 2}$, and $\mathrm{ERK}_{1}$.

期への移行には, cyclin-dependent kinase (CDK) 4, c-myc, cyclin D3, p21 及び p27 が関与しているこ とが知られている. SAL 処理によるこれらのタン パク質発現量の変化を検討した結果，CDK4，cmyc, 及び cyclin D3 の発現が減少し, 反対にp21 と p27 は SAL 処理により発現が上昇することが明 らかとなった (Fig. 3). ${ }^{41)}$ 次に, ERK 経路に着目 してこれらの分子の制御機構について検討したとこ ろ, SAL 処理により Ras-MEK-ERK 経路が 活性化 するという結果が得られた（Fig. 4)。この結果を 単純に解釈すると細胞を増殖させる方向に働くこと になり，SAL が細胞増殖を抑制する，という事実 と相反することからメカニズム解明を悩ませた。し 
A

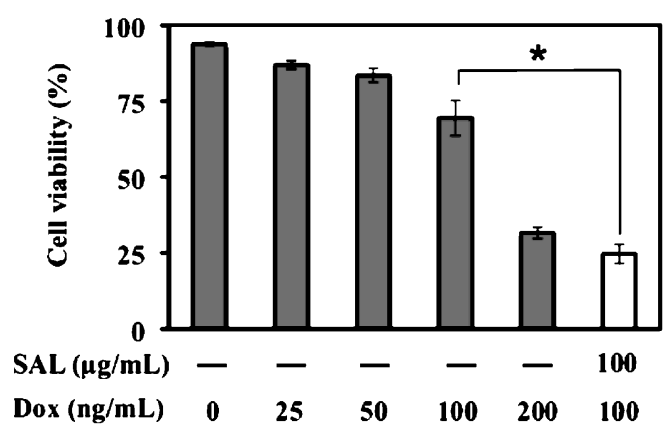

B
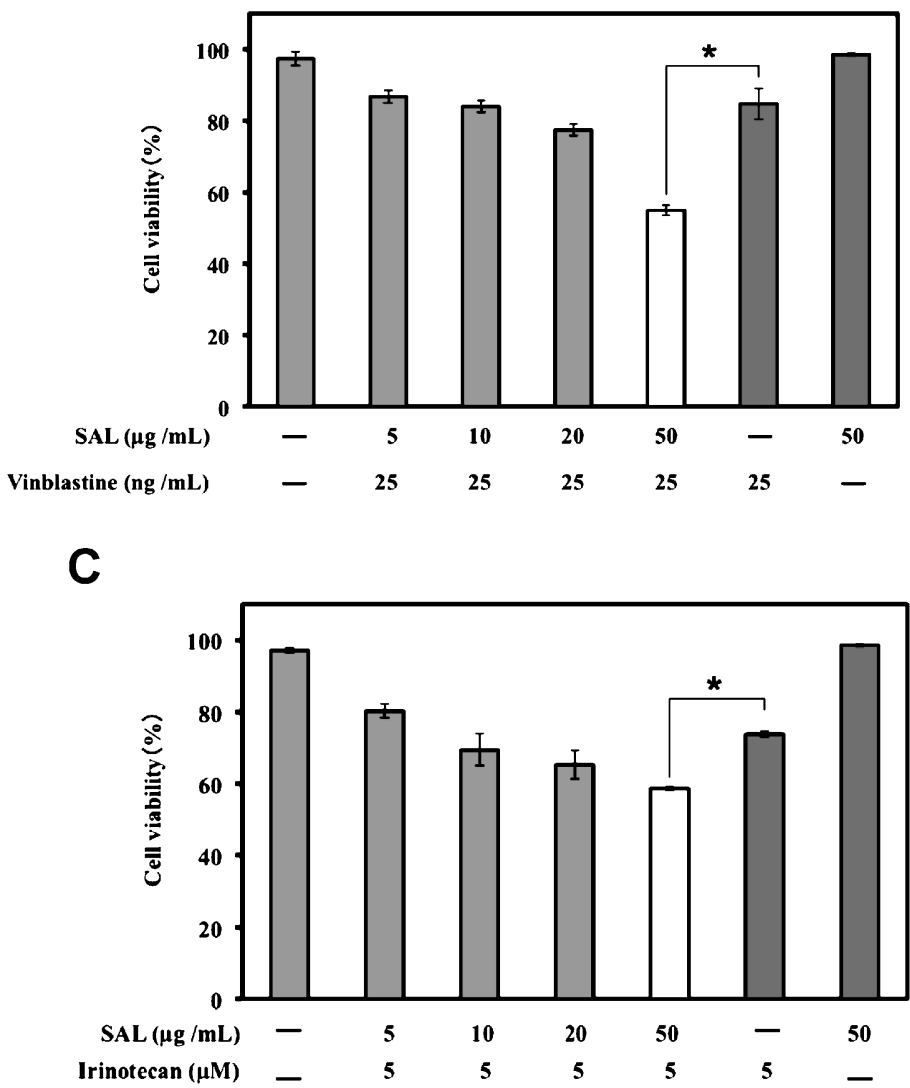

Fig. 5. Cytotoxic Effect of Anti-cancer Drugs in Raji Cells Pre-treated with SAL

(A) Cells $\left(5 \times 10^{4}\right)$ were treated with Dox $(25,50,100,200 \mathrm{ng} / \mathrm{mL})$ at $37^{\circ} \mathrm{C}$ for $60 \mathrm{~h}$. Raji cells pre-treated with $100 \mu \mathrm{g} / \mathrm{mL} \mathrm{SAL}$ at $37^{\circ} \mathrm{C}$ for $24 \mathrm{~h}$, were subjected to treatment with Dox $(100 \mathrm{ng} / \mathrm{mL})$ at $37^{\circ} \mathrm{C}$ for $60 \mathrm{~h}$. (B) Raji cells pre-treated with SAL $(5,10,20$ and $50 \mu \mathrm{g} / \mathrm{mL})$ at $37^{\circ} \mathrm{C}$ for $24 \mathrm{~h}$ were treated with vinblastine $(25 \mathrm{ng} / \mathrm{mL})$ at $37^{\circ} \mathrm{C}$ for $48 \mathrm{~h}$. (C) Raji cells pre-treated with SAL $(5,10,20$ and $50 \mu \mathrm{g} / \mathrm{mL})$ at $37^{\circ} \mathrm{C}$ for $24 \mathrm{~h}$ were treated with irinotecan $(5 \mu \mathrm{M})$ at $37^{\circ} \mathrm{C}$ for $48 \mathrm{~h}$. Cell viability was measured by trypan blue dye exclusion assay. Each value represents the mean \pm S.E. for three independent experiments. ${ }^{*} p<0.05$ versus doxorubicin, vinblastine, or irinotecan-treated cells.

かし，2011 年にMoon らにより，JNK 阻害剂 SP600125 で処理された細胞では，ERKのリン酸化 レベル上昇に伴い，転写因子である $\mathrm{Sp} 1$ が活性化 することにより, p21の発現が上昇し細胞増殖を抑 制するという報告がなされた. ${ }^{42)} \mathrm{SAL}$ もこれと同様 の作用機序を持つとすれば，一連の結果を矛盾なく 説明できるかもしれない。現在，この仮説を証明す るエビデンスを得るための実験が進行中である.

\section{SAL と抗がん剂との併用効果}

ヨウ化プロピジウム (propidium iodide；PI) は, 細胞膜が健全な生細胞には取り込まれず，細胞死に より細胞膜が崩壊した細胞に取り込まれることが知 られている，先にも述べたように，SAL は細胞死 を誘導しない。しかし，理由は分からないが，細胞 膜不透過物質である PI が SAL 処理細胞には促進 的に取り込まれるという興味深い現象を見い出した 
[Fig. 1 (B) ]．この現象をがん治療に応用できなか いと考え，PI を抗がん剤に置き換えて SAL と抗が ん剤との併用効果について検討した.

まずはじめに，ドキソルビシン（doxorubicin; Dox）との併用効果を検討した. Dox の持つ自家蛍 光を利用して細胞内の取り込み量を測定した結果, SAL 処理により増加していることが示された. ${ }^{43)}$ Dox は, 処理濃度依存的に Raji 細胞の生存率を低 下させるが, SAL を前処理することにより生存率 がさらに低下し, $100 \mathrm{ng} / \mathrm{mL}$ の Dox と SAL の併用 により, $200 \mathrm{ng} / \mathrm{mL}$ の Dox 処理と同程度まで生存 率を低下させることが示された $[$ Fig. 5(A)]。さら に，他の抗がん剂との併用も検討したところ， 25 $\mathrm{ng} / \mathrm{mL}$ ビンブラスチン（vinblastine; Vin）単独処 理時の Raji 細胞の生存率は $85 \%$ であったが, SAL を併用することにより生存率が $55 \%$ まで低下した [Fig. 5(B) ]。イリノテカン（irinotecan; Iri）も同 様に SAL 併用時における生存率の変化を調べたと ころ，5 $\mu \mathrm{M}$ Iri 単独処理では生存率が 74\%であった が，SAL との併用により生存率が 59\%に低下した [Fig. $5(\mathrm{C})$ ］. ${ }^{44)}$ これらの結果から，抗がん剂を SAL と併用することにより薬剤の濃度を下げても 高濃度と同じ効果を得られることが分かった．抗が ん剂治療で最も問題となるのは副作用の発現である が，SAL は，がん細胞の薬剂感受性を高める効果 を発揮することでこの問題を解決できる可能性を有 している。 また，バーキットリンパ腫のみならず Gb3 を発現しているがん細胞であれば, SAL は併 用する抗がん剂の用量低減に貢献できる可能性を有 するものと考えている.

7. おわりに

RBL のがん細胞に対する作用は，前述した CSL3 と SAL では異なり，前者は cytotoxic に，ま た後者は cytostatic に働く，この要因が, レクチン 分子の CRD 組成による（それぞれ 2 個及び 3 個） か否かを証明するエビデンスはまだ得られていない が，CSL3 と同様に 2 個の CRD からなる OLL は, SAL と異なり cytotoxic な作用を示すことを確認し ている，表面プラズモン共鳴スペクトル（surface plasmon resonance; SPR）解析により，SAL と OLL の糖結合性を速度論的に比較したところ, $\mathrm{Gal} \alpha$ 結合及び $\mathrm{Gal} \beta$ 結合に対する親和性は, $\mathrm{SAL}$ が Gal $\alpha \gg \mathrm{Gal} \beta$ である一方, OLL は $\mathrm{Gal} \alpha \geqq \mathrm{Gal} \beta$
で，若干の相違が認められた。この傾向は，レクチ ンの Raji 細胞への結合性が, SAL の場合抗 Gb3 抗 体の前処理でほぼ完全に阻害されるのに対し,

OLL では同じ処理でも結合が一部残存するという 結果にもあらわれている。すなわち，Gb3のみを 介する SAL の cytostatic な作用は，同時に $\mathrm{Gal} \beta$ 結 合を介する他の糖鎖との相互作用の追加により cytotoxic な方向に舵を切るようになるのではない か. また, Gb3 発現のみられない K562 細胞に Gb3 を強制発現させると, SAL の結合は観察されるも のの, Raji 細胞でみられるような細胞縮小や増殖 抑制は起こらない。 そもそも Gb3 は膜貫通分子で はないので, SAL のシグナルを細胞内に伝達する ためのアダプター分子の存在が推測されたことか ら, 現在 Gb3 の近傍に存在し，かつ RBL の結合に よりシグナルを仲介する分子を, enzyme-mediated activation of radical sources（EMARS）法などを駆 使して探索中である. ${ }^{45)}$ さらに最近，がん細胞の種 類により Gb3 の分子組成（主にセラミド部分を構 成しているアシル鎖の違い) が異なり，それに伴つ て SAL の効果も変化するという興味ある知見も得 ている.

抗腫瘍戦略にレクチンを参入させる新しい試みが 最近報告された。 2017 年に筑波大学と産業技術総 合研究所のグループが Burkholderia cenocepacia 由 来の BC2LC-N レクチンに緑膿菌外毒素である PE38 を融合させた lectin drug conjugate（LDC）を 開発し，膵がんを標的とした抗腫瘍薬創製の可能性 を示した。この LDC の膵がん細胞株に対する効果 は, 既存の抗体一薬剂融合体 (antibody-drug conjugate; ADC) よりも 1000 倍高く，かつマウスを 用いたin vivo の実験でもその効果が確認された. ${ }^{46)}$ これはレクチンが標的細胞を捕捉する能力において 抗体を凌駕している点で, 従来の認識を覆す重要な 知見である．またこの報告は，レクチンのがん治療 への応用に道を拓くものであり, 今後 LDC の応用 研究が加速されていくことになろう。一方で，筆者 のナマズ卵レクチンによる,「がん細胞の薬剤感受 性を高め, 副作用を軽減する」戦略も，LDC とは コンセプトが異なるが，これまでにないユニークな ものであると考えている. 細胞膜ラフト画分におけ る Gb3 の機能解明あるいは未同定の仲介タンパク 質の解析など課題は山積しているが，「レクチンに 
よるがん治療」実現に向けて研究を進めていきたい.

\section{謝辞本研究は東北医科薬科大学薬学部分子認} 識学教室 細野雅祐教授並びに仁田一雄名誉教授の 指導により行われた研究成果であります。この場を 借りて御礼申し上げます。本総説中で述べた当研究 室関連の研究の一部は, 文部科学省私立大学戦略的 研究基盤形成支援事業の助成により行われたもので す.

\section{利益相反＼cjkstart開示すべき利益相反はない.}

\section{REFERENCES}

1) Varki A., "Essential of Glycobiology,” ed. by Varki A., Cummings R., Esko J., Freeze H., Hart G., Marth J., Cold Spring Harbor Laboratory Press, Cold Spring Harbor, 1999.

2) Dodson K. W., Pinkner J. S., Rose T., Magnusson G., Hultgren S. J., Waksman G., Cell, 105, 733-743 (2001).

3) Karlson K. A., Annu. Rev. Biochem., 58, 309350 (1989).

4) Krajhanzl A., Adv. Lectin Res., 3, 83-131 (1990).

5) Satoh T., Tatsuta T., Sugawara S., Hara A., Hosono M., Oncotarget, 8, 42466-42477 (2017).

6) Tatsuta T., Satoh T., Sugawara S., Hara A., Hosono M., PLoS One, 13, e0190653 (2018).

7) Barondes S. H., Castronovo V., Cooper D. N. W., Cummings R. D., Drickamer K., Feizi T., Gitt M. A., Hirabayashi J., Hughes C., Kasai K., Leffler H., Liu F. T., Lotan R., Mercurio A. M., Monsigny M., Pillai S., Poirer F., Raz A., Rigby P. W. J., Rini J. M., Wong J. L., Cell, 76, 597-598 (1994).

8) Barondes S. H., Cooper D. N. W., Gitt M. A., Leffler H., J. Biol. Chem., 269, 20807-20810 (1994).

9) Hosono M., Kawauchi H., Nitta K., Takayanagi Y., Shiokawa H., Mineki R., Murayama K., Biol. Pharm. Bull., 16, 239243 (1993).

10) Hosono M., Ishikawa K., Mineki R., Murayama K., Numata C., Ogawa Y., Takayanagi Y., Nitta K., Biochem. Biophys. Acta, 1472, 668675 (1999).
11) Hosono M., Kawauchi H., Nitta K., Takayanagi Y., Shiokawa H., Mineki R., Murayama K., Biol. Pharm. Bull., 16, 1-5 (1993).

12) Hosono M., Matsuda K., Kawauchi H., Takayanagi Y., Shiokawa H., Mineki R., Murayama K., Nitta K., Biomed. Res., 13, 443-449 (1992).

13) Tateno H., Saneyoshi A., Ogawa T., Muramoto K., Kamiya H., Saneyoshi M., J. Biol. Chem., 273, 19190-19197 (1998).

14) Shiina N., Tateno H., Ogawa T., Muramoto K., Saneyoshi M., Kamiya H., Fish. Sci., 68, 1352-1366 (2002).

15) Hosono M., Sugawara S., Matsuda A., Tatsuta T., Koide Y., Hasan I., Ozeki Y., Nitta K., Fish. Physiol. Biochem., 40, 1559-1572 (2014).

16) Shirai T., Watanabe Y., Lee M., Ogawa T., Muramoto K., J. Mol. Biol., 391, 390-403 (2009)

17) Hatakeyama T., Ichise A., Unno H., Goda S., Oda T., Tateno H., Hirabayashi J., Sakai H., Nakagawa H., Protein Sci., 26, 1574-1583 (2017) .

18) Tateno H., Ogawa T., Muramoto K., Kamiya H., Saneyoshi M., Biosci. Biotechnol. Biochem., 66, 1356-1365 (2002).

19) Terada T., Watanabe Y., Tateno H., Naganuma T., Ogawa T., Muramoto K., Kamiya H., Biochem. Biophys. Acta, 1770, 617-629 (2007).

20) Watanabe Y., Shiina N., Shiozaki F., Yokoyama H., Kominami J., Nakamura-Tsuruta S., Hirabayashi J., Sugahara K., Kamiya H., Matsubara H., Ogawa T., Muramoto K., Dev. Comp. Immunol., 32, 487-499 (2008).

21) Jimbo M., Usui R., Sakai R., Muramoto K., Kamiya H., Comp. Biochem. Physiol., B147, 164-171 (2007).

22) Yu H., Murata K., Hedrick J. L., Almaraz R. T., Xiang F., Franz A. H., Arch. Biochem. Biophys., 463, 1-11 (2007).

23) Nitta K., Kawano T., Sugawara S., Hosono M., Yakugaku Zasshi, 127, 553-561 (2007).

24) Ogawa T., Watanabe M., Naganuma T., Muramoto K., J. Amino Acid, 838914 (2011).

25) Thongda W., Li C., Luo Y., Beck B. H., Peatman E., Dev. Comp. Immunol., 44, 320-331 
(2014) .

26) Kageyama A., Kusano I., Tamura T., Oda T., Muramatsu T., Biosci. Biotechnol. Biochem., 66, 835-839 (2000).

27) Ohba H., Moriwaki S., Bakalova R., Yasuda S., Yamasaki N., Toxicol. Appl. Pharmacol., 195, 182-193 (2004).

28) Hajtó T., Berki T., Boldizsár F., Németh P., Immunol. Lett., 86, 23-27 (2003).

29) Dias-Baruffi M., Zhu H., Cho M., Karmakar S., McEver R. P., Cummings R. D., J. Biol. Chem., 278, 41282-41293 (2003).

30) Katagiri Y. U., Mori T., Nakajima H., Katagiri C., Taguchi T., Takeda T., Kiyokawa N., Fujimoto J., J. Biol. Chem., 274, 3527835282 (1999).

31) Fadeel B., Gleiss B., Högstrand K., Chandra J., Wiedmer T., Sims P. J., Henter J. I., Orrenius S., Samali A., Biochem. Biophys. Res. Commun., 266, 504-511 (1999).

32) Bratton D. L., Fadok V. A., Richter D. A., Kailey J. M., Guthrie L. A., Henson P. M., J. Biol. Chem., 272, 26159-26165 (1997) .

33) van Helvoort A., Smith A. J., Sprong H., Fritzsche I., Schinkel A. H., Borst P., van Meer G., Cell, 87, 507-517 (1996).

34) Borst P., Zelcer N., van Helvoort A., Biochim. Biophys. Acta, 1486, 128-144 (2000) .

35) Sugawara S., Hosono M., Ogawa Y., Takayanagi M., Nitta K., Biol. Pharm. Bull., 28, 434-441 (2005).

36) Okada Y., Maeno E., Shimizu T., Dezaki K., Wang J., Morishima S., J. Physiol., 532, 3-16
(2001).

37) Bortner C. D., Cidlowski J. A., Biochem. Pharmacol., 56, 1549-1559 (1998).

38) Kawano T., Sugawara S., Hosono M., Tatsuta T., Ogawa Y., Fujimura T., Taka H., Murayama K., Nitta K., Biol. Pharm. Bull., 32, 345-353 (2009).

39) Watanabe Y., Tateno H., Nakamura-Tsuruta S., Kominami J., Hirabayashi J., Nakamura O., Watanabe T., Kamiya H., Naganuma T., Ogawa T., Naudé R. J., Muramoto K., Dev. Comp. Immunol., 33, 187-197 (2009).

40) Qin J., Shang L., Ping A. S., Li J., Li X. J., Yu H., Magdalou J., Chen L. B., Wang H., Arthritis. Res. Ther., 14, R242 (2012).

41) Sugawara S., Im C., Kawano T., Tatsuta T., Koide Y., Yamamoto D., Ozeki Y., Nitta K., Hosono M., Glycoconj. J., 34, 127-138 (2017).

42) Moon D. O., Choi Y. H., Kim G. Y., Cell. Mol. Life. Sci., 68, 3249-3260 (2011).

43) Sugawara S., Sasaki S., Ogawa Y., Hosono M., Nitta K., Yakugaku Zasshi, 125, 327-334 (2005) .

44) Sugawara S., Araya K., Hosono M., Tatsuta T., Nitta K., J. Tohoku Pharm. Univ., 58, 4146 (2011).

45) Kotani N., Gu J., Isaji T., Udaka K., Taniguchi N., Honke K., Proc. Natl. Acad. Sci. USA, 105, 7405-7409 (2008).

46) Shimomura O., Oda T., Tateno H., Ozawa Y., Kimura S., Sakashita S., Noguchi M., Hirabayashi J., Asashima M., Ohkohchi N., Mol. Cancer Ther., 17, 183-195 (2018) . 